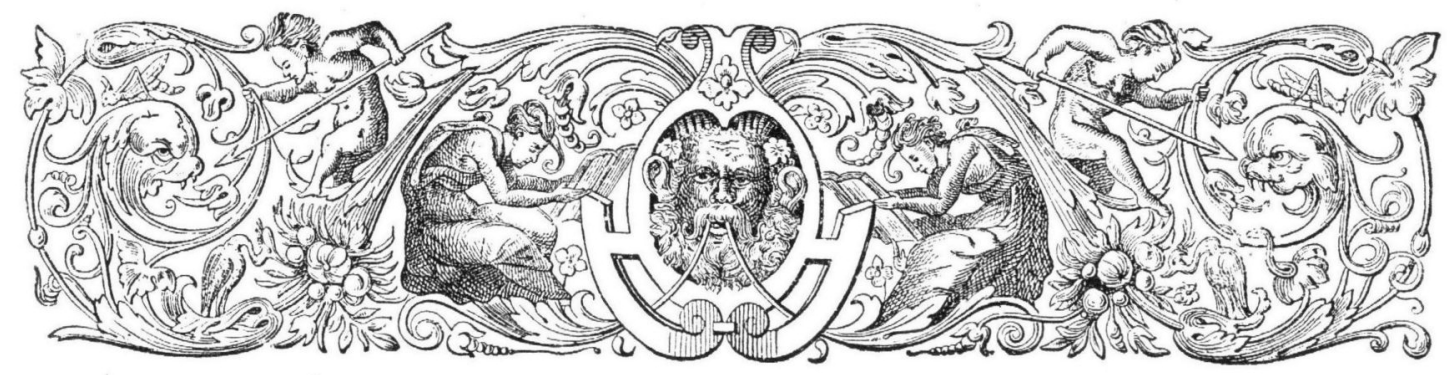

\title{
DE ACADEMIE TE NIJMEGEN')
}

DOOR

DR. Y. H. ROGGE.

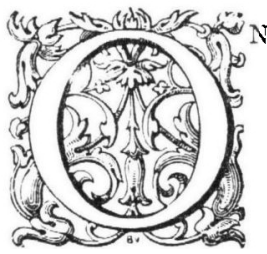

NDER de papieren van Cornelis Walraven Vonck, die te Arnhem bewaard worden, is een bundel getiteld: Miscella. Hierin vinden wij anteckeningen van VONCK vooral betrekking hebbende op de geschiedenis van het geleerde Nijmegen, waarover hij een boek wilde schrijven. Wij lezen daar o. a. deze aanteekening: „ad Historiam Erud. Noviom. confer Martini Schoockil Belgium Foederatum Lib. XVI, Cap. 6, ubi, si bene memini, de academia Tetrarchiae Noviomag. agitur." VONCK's memorie was goed, want werkelijk spreekt ScHOOCK op dic plats over de voor eenige jaren opgerichte academie. Laat ik deze belangrijke woorden geheel aanhalen: „Placuit quoque ante annos aliquot ordinibus Tetrar-

1) Over deze academie schreven :

TH. L. Roukens, Oratio de Academia Noviomagensi. Gron. 1769 .

Huygens, Beschrizizing van het Begin, Qpkomst in Aanwas der stad Doesbirg, Nijmegen i753. Zie de voorrede van C. Walkaven Vonck.

F. in de Betouw, Quartierijke Academie en Apostolische of Latijnsehe school te Nijmegen, z. j.

P. Nijhoff, De Akademie te Nijmegen, Geldersche Volksalm. I864.

J. C. F. VAN der MEer van Kuffeler, De voormalige Illustre-School en Academie te Nijmegcn, Tijdspiegel, r8go.

Oud-Holland 1900. 
chiae Noviomagensis Noviomagi erigere Academiam. In qua licet occurrant sex professores, qui praeter tres superiores facultates omnes quoque philosophiae partes (mathesi non excepta) itemque eloquentiam et historias docent, ad hoc actus promoterii instituti fuerint, cum tamen alterarum duarum Tetrarchiarum ordines perpetuo Academiae huic restiterint et suprema provinciae curia renucrit inter advocatos admittere juris doctores hic creatos ${ }^{1}$ ), Academia Noviomagensis hactenus controversi juris censeri debet. Optandum foret, Academia Harderovicena Noviomagum (quae civitas longe amplior et commodior est) tranferretur."

De vraag, in hoeverre de beide andere Quartieren zich verzet hebben tegen het oprichten van een academie te Nijmegen, is gemakkelijk te beantwoorden. De recessen van de Quartieren en Landdagen geven ons voldoende inlichtingen. In I647 werd op den Landdag besloten, dat de drie Quartieren gezamenlijk de kosten van de Harderwijksche school zouden dragen, daar de inrichting in verval geraakte en het onderhoud te duur was voor het Quartier der Veluwe alleen. Wel-is-waar trachtte het Quartier van Nijmegen zich te verzetten, daar het de gelegenheid te schoon vond om niet te beproeven, of een Illustre School te Nijmegen kon geopend worden, maar het verzet was te vergeefsch. De academie te Harderwijk bleef achteruitgaan en hierin zag Nijmegen steeds een reden om aan te dringen op verplaatsing. Eindelijl, 5 October 1653 , besloot het Quartier de subsidie te geven aan den magistraat van de stad Nijmegen „tot vollest van de costen van eene Illustre School, die in haere stadt gefundiert ende aengestelt sal worden." Dit besluit werd ter vergadering van HH. Gedeputeerden ad causas ingebracht op 7 October. Nadat alles was meegedeeld, teekenden de Quartieren van Zutphen en de Veluwe verzet aan, omdat, zoo zeiden zij, het voorstel geheel ongerijmd was. Immers de academie te Harderwijk was door de drie Quartieren ingesteld en men had hiervan octrooi verleend, zoodat het hierop zou neerkomen: een resolutie van den Landdag te verbreken. Schreed men op dezen weg voort; dan zouden alle verleende octrooien ingetrokken kunnen worden, iets wat toch niet aanging. Het antwoord der Nijmeegsche heeren was kort en de argumenten waren dezelfde als voorheen. $\mathrm{Zij}$ beriepen zich op het verval der academie en op het feit, dat er geen woord tegengesproken was, toen zij de subsidie hadden opgezegd. Deze opzegging had plaats gehad in I65I. Op hun vergadering van Io Juli besloten de Gedeputeerden van het Quartier het volgende: „Het Quartier, gelet op haren beswaerlicken staet en groote tachterheyt ziet zich genoodzaakt het jaarlijksch subsidium aan de academie te Harderwijk op te heffen en niet

1) BARBEYRAC vertelt in het levensbericht van GERARD Noodt hetzelfde: „Quin etiam Provinciae Curia suprema inter advocatos admittere juris doctores Neomagi creatos abnuebat." 
verder te betalen, ten ware men mocht overeenkomen die academie naar een geschikte plaats over te brengen, hetwelk ter vergaderingh van de lantschap also ingebracht sal worden." 3 I Juli werd dit bij den Landdag ingebracht, alleen vinden wij in het reces aan het slot nog deze woorden : „off dat door gecommitteerden uit de resp. quartieren gedurende der landtschaps vergaderinge eene conferentie moge worden gehouden ende voorslagen gedaen, hoe het vervall van de academie geremedieert ende voorgecomen soude connen worden."

Heeft Nijmegen niet meer de subsidie betaald en is het verzet der Quartieren van Zutphen en de Veluwe ijdel geweest? Mij dunkt de Harderwijksche rekeningen, waarin tot aan 1672 de volle toelagen der drie Quartieren door den rentmeester verantwoord zijn, kunnen niet liegen. Het Quartier van Nijmegen heeft slechts gedreigd, maar is geëindigd met te betalen, al was het met bloedend hart. Intusschen werd de Illustre School te Nijmegen 3 Mei 1655 geopend en stelde het Quartier een bedrag van 3757 g. I 3 st. 4 penn. vast als subsidie ${ }^{1}$ ). Waarschijnlijk heeft men te Nijmegen gemeend, dat men door deze opening het pleit zou winnen. Immers wanneer het bleek, dat de academie te Harderwijk steeds meer en meer achteruitging en de Illustre School te Nijmegen in bloei toenam, was te verwachten - zoo hoopte tenminste de Raad - dat de beide Quartieren toegaven. Deze verwachting werd teleurgesteld, maar toch hield Nijmegen niettegenstaande de groote kosten vol. Schoorvoetend deed men de eerste stappen, steeds hopende, dat geheel Gelderland de academie zou erkennen. Zeer duidelijk zien wij dit, toen in den Raad aan de orde kwam de jurisdictie over de studenten. Evenals in de overige universiteitssteden besloot inen de jurisdictie in gevallen van minder ernstigen aard over te laten aan een academieraad, terwijl de groote misdrijven ,saecken daer Lijf, Leven of Lith aenhangt, mitsgaders openbaer gewelt, vrouw ofte Maegde-schenderij, 't sij met wil of in weerwil deselve, alsmede alle Huwelijxe saeken, met den aencleven van dien" zouden blijven "ter judicature ende Executie van den Raedt ofte Schepenstoel der stad Nijmeegen." Het concept voor deze academieraad werd gelezen en geëxamineerd in de Raadszitting van 2 Februari 1659. De Raad besloot niet te beslissen, voordat de Quartieren van Zutphen en de Veluwe zich voor de academie hadden verklaard, maar schijnt weldra begrepen te hebben, dat men daarop lang zou kunnen wachten, want reeds den 29sten Maart nam hij het concept aan. Op hetzelfde wijst het raadsignaat van 12 September I659, waar wij lezen: „De heere Borgem. GORIS, soo met den Secretaris COENRAET KLERCK gecommitteert

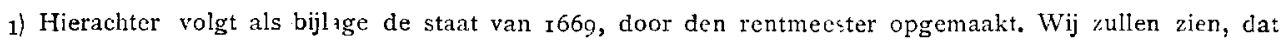
de subsidie niet voldoende was voor het onderhoud der academie. 
is geweest omme aen de magistraten van Tiel ende Bommel te versoecken, ten eijnde haer E. gecommittierden, soo op den Landtdach tot Arnhem sullen compareren, willen helpen coöpereren, dat de provinciale academie van Harderwijck hier getransporteert worden, hebbende van haer $E$. wedervaren rapport gedaen van dat opgemelte magistraten haer daertoe genegen getoont hebben, sijn voor hare aangewendte moeijten in desen bedanckt" ').

In het bericht van ScHOOCK lezen wij verder, dat ook de „actus promotorii" bij deze academie zouden zijn ingesteld, maar dat het Hof van Gelderland zou geweigerd hebben als advocaten toe te laten hen, die te Nijmegen promoveerden. Voorzeker men kon te Nijmegen promoveeren. Het bewijs hiervoor valt niet alleen te halen uit de raadsbesluiten, doch ook uit de leges, gemaakt bij de oprichting. Niets is meer overgebleven van de papieren en stukken, betrekking hebbende op de universiteit, behalve één gedrukt blad, waarop eenige leges staan ${ }^{2}$ ), en daaronder deze bepaling: quicunque supreman Doctoris lauream expetere volent, prius Rectori Magnifico quadraginta florenos solvento. De gelegenheid bestond derhalve, en er is ook door verschillende studenten gebruk van gemaakt. In de eerste plaats toonen de volgende raadsignaten dit aan:

9 April 1656. Also seecker student in den Rechten versocht heeft in dese Illustre Schole tott doctor juris gepromoviert te moegen worden, Is goet gevonden t'selve die Heeren Gedeputeerden bekent te maecken, met versoeck, dat haer Ed. tott sodaene promotie consent gelieve te draegen op approbatie vant quartier.

28 Mei 1656. Alsoo seecker student in den Rechten eerstdaeghs in de universiteijt alhier gepromoviert ende doctor juris gecreeert sall worden, Is goet gevonden tott gedachtenis van dien, als sijnde sulcx noijt voor desen geschiedt, eenige golde penningen te doen slaen ter weerde van omtrent seszendedartich gulden ijder, om aen de professoren und daer het voorts behoren sall, vereert te worden ${ }^{3}$ ).

1) Vergel. ook het quartiersreces van 24 September 1659 . Om aan te toonen, dat de academie van Harderwijk geheel vervallen was, werd er op gewezen, hoe Ds. Christenius, beroemd professor, een beroep naar Amsterdam had aangenomen "in obscuro gymnasio."

2) Het fragment van deze bepalingen, dat de archivaris H. D. J. VAN SCHevichaven toevallig vond, volgt als bijlage.

3) De naam van dezen student is ons bekend nl. Petrus Jordan. Op deze promotie maakte JoAnnes vaN SOMEREN een gedicht, zie: J. v. SOMEREN, Uyt-Spanning der Vernuften, bestaende in Geestelijcke ende Wereltlijcke poësy, Nijmegen I660 bl. 289 De titel luidt: Praeclarissimo Juveni D. Petro Jordan, cum summos in utroque jure honores in Alma Tetrarchiae Noviomag. Universitate publice obtineret. Van SOMEREN wassyndicus van Nijmegen. 6 December 1654 besloot de Raad, dat de curatoren vaN WELDEREN en VERHEIJDEN met den burgemeester GoRIS en dea raadsvriend vaN BENTHEM naar Leiden zouden reizen om te beproeven, of professor Hornius naar Nijmegen wilde komen. Op deze reis moesten zij tevens Dordrecht bezoeken en den advocaat vaN SOMEREN het ambt van pensionaris aanbieden. De laatste nam de benoeming aan en bezwoer zijn instructie op I $_{4}$ Februari 1655 . 
27 Mei I657. Opt voorstel, van wegen den Rector Magnificus gedaen sal seecker student in de Medicinen, die van meijninge is sich doctor te laeten promovieren, eenen golden penningh vereert worden ter weerde met het snijen ende fatsoen van vertich gulden.

2 I October 1657. N. STRAETMAN sijnde die eerste, die magister artium in d'academie alhier gepromoveert sal worden, hebben mijn heeren toegestaen, dat voor hem eenen gouden penninck van XXV gulden gemaect sal worden ${ }^{1}$ ).

In de tweede plaats lezen wij bij Rotkess: „Nominabo quosdam, quorum partim diplomata, partim disputationes oculis meis ipse usurpavi:

Johannes van Teffelen, Tyla-Gelrus, Med. Doct. i6 Juni 1662.

Jacobus van Hervelt, Noviomagus, Med. Doct. 1670.

Johannes Lemmers, Theol. Doct. $\left.\pm 1670^{\circ}\right)$.

Ex chronico manuscripto JoHannis SMetil.

Abrahamus van Senden, Amstelodamo-Batavus. i 2 Febr. 1678.

Quod ideo monendum duxi, quia in ipsa yatria de his promotionibus dubitantes viros non infimae ordinis ipse audivi." Roukens' geloofwaardigheid is boven verdenking. Daarenboven wordt in de radsignaten van 1662 gesproken over de promotie van vaN TEFFELEN. De Nijmeegsche jongens maakten bij de promoties, die in de Stephenskerk plaats vonden, groot rumoer en daarom besloot de Raad, dat voortaan de plechtigheid in het auditorium van de academie zou geschieden ").

Wanneer nu vaststaat, dat studenten te Nijmegen gepromoveerd zijn, zoo blijft de vraag over, of soms aan te toonen is, dat velen hun titel aan een andere universiteit behaalden, omdat de Nijmeegsche academie niet erkend werd en het Hof van Gelderland, gelijk SCHOOCK bericht, geen juris doctores uit die stad toeliet. Ik hoop in het volgende te kunnen bewijzen, dat vooral de juristen het verstandiger oordeelden elders zich tot doctor te laten bevorderen.

De bibliotheek te Arnhem bezit een collectie disputationes, door Nijmeegsche studenten gehouden aan de academie te Nijmegen. Laat ik beginnen met deze disputaties op te geven, zooals zij voorkomen in den catalogus der Arnhemsche bibliotheek:

I. I. VAN DEN BERGH, de testamento solenni.

2. J. BORs, de usufructu.

1) In Utrecht kreeg Justus KRIxiUs, de eerste, die als doctor juris promoveerde op I December $163^{6}$, een vergulden beker. De beschrijving hiervan vinden wij bij Bexthex, Hollündischer Kirch-und Schulen Siaat.

2) In het rekenboek van $166_{3}$ lezen wij: .Aen verscheijde speelluyden betaelt $I_{5}$ gulden, als wanneer Dominus LEMMiNCX in de theologie gepromoveert is." Zou hier bij Rovkess geen fout schuilen? Hij zelf geeft op, dat hij den titel alleen bij suerius gevonden heeft, De dissertatie is blijkbaar niet door hem gezien.

3) Zie het raadsign. van 22 Juni $\mathbf{I} 662$. 
3. W. Craeivanger, de societate.

4. G. VAN DALEN, de fidei commissariis haeredit.

5. J. A GaEsbeEk, de evictionibus.

6. A. DE GREVE, de usufructu.

7. " " $"$ de foro competenti.

8. . " " $"$ de jure dotium.

9. G. AB HAM, de compensationibus.

I0. J. A. LIDT DE JEUDE, de rei vindicatione.

II. J. DE JONCKHEERE, de publicis judiciis.

I2. G. KELFKEN, Conclus. ex contract. materia.

I3. G. NoodT, de transactionibus.

I4. " " de possessione.

I5. J. DE ROOIJ, de pignoribus et hypothecis.

i6. E. Tengnagel, de mutuo.

I7. J. Verbolt, de usufructu.

I8. " " $"$ de fidejussoribus.

19. A. Wentholt, de usuris, mora et fructibus.

20. O. VAN DEN BERGH, de natura mentis.

2I. JAC. AB HERVELT, de natura hominis.

22. Joh. Fildar, de ideis.

23. JoH. TeIler, de anima philosophiae.

Deze opgave uit den catalogus stemt niet overeen met hetgeen men mij kon overleggen, daar No. 4, 5 en I 5 niet aanwezig waren. Misschien zijn zij zoek geraakt. Verder moeten vervallen No, I I en 12 . Immers het zijn geene disputationes, gehouden te Nijmegen, maar te Leiden. alleen zijn zij te Nijmegen gedrukt, omdat DE JONCKHEERE en KELFKEN Nijnegenaars van geboorte waren. Wanneer wij nu, nadat de lijst gezuiverd is van dat, wat er niet op thuis hoort, de titelbladen bekijken, vinden wij slechts op één blad vermeld, dat de disputatio geschreven werd om den doctorsgraad te behalen. Het is in het boekje van TeILER, waar wij lezen: Disputatio philosophica inauguralis: de anima philosophiae; pro gradu doctoratus et summis in philosophia privilegiis consequendis, $\mathbf{} 668$. Deze promotie had plaats onder leiding van Samuel Tfinnulius, die i 2 November I666 op een tractement van Soo gl. naar Nijmegen beroepen was als oprolger van Johannes Schulting.

De laatste vier studenten, waaronder ook TEILER, schreven over philosophische onderwerpen. $\mathrm{Nu}$ staat in de boekjes van v. D. BERGH, FILDAR en VAN HeRvelt: exercitationum philosophicarum miscellanearum secunda etc., zoodat wij hier te doen hebben met oefeningen, die de studenten hielden onder 
hunne professoren, en niet met dissertaties, waarmee de doctorstitel behaald werd. De vraag is thans, of deze drie te Nijmegen gepromoveerd zijn. Voor één kan $\mathrm{ik}$ dit stellig ontkennen. Immers OTTO VAN DEN BERGH promoveerde 4 December 1676 te Leiden met een dissertatie "de Pica". Ook de namen van FILDAR en VAN HERVELT trof $\mathrm{ik}$ in het Album Studiosorum van Leiden aan, maar of zij daar gepromoveerd zijn, bleef in het onzekere. Wat TEILER betreft, ook hij bezocht Leiden na zijn promotie en liet zich inschrijven als Philosophiae Doctor. Een oplossing, waarom TEILER te Nijmegen promoveerde en de andere drie Nijmegen voor hun promotie verlieten, is te vinden, al is natuurlijk wat ik zal zeggen slechts een vermoeden. Of men elders den titel te Nijmegen verkregen erkende, kon TEILER wcinig schelen; hij toch bleef te Nijmegen en was misschien in zijn studententijd reeds aangewezen als professor, wanneer er een vacature kwam in de wiskundige of philosophische vakken. Wij zien dan ook, dat bij het vertrek van professor CRANEN in April I670 naar Leiden, ThoMAS Pels en JoHAN TeILer als opvolgers worden aangewezen '). De andere drie, liever het zekere voor het onzekere gekozen hebbende, behaalden den doctorsgraad aan een andere universiteit.

Wij gaan over tot de juristen. Te voren zeide ik, dat de lijst na aftrek van vijf namen gezuiverd was. Dit strookte nog niet geheel met de waarheid, omdat er twee dissertaties op zijn blijven staan, die wij eigenlijk ook moeten schrappen. Het zijn No. 7 en I8. Gelijk uit de lijst blijkt, staan No. 6, 7 en 8 op naam van ALbERTUS DE GREVE, maar dit is niet een en dezelfde persoon. De eerste twee boekjes zijn geschreven door AïBERTUS DE GREVE, zoon van den Nijmeegschen Hoogleeraat Petrus DE GREvE, het laatste werkje is van de hand van Albertus de Greve, zoon van den secretaris te Grave: Willem DE Greve. Petrus en Willey waren broeders. Zoodra wij No. 6 en 7 bekijken, zien wij een groot verschil. Op de disputatio de usufructu staat niet vermeld, dat $z \mathrm{ij}$ gehouden werd ter verkrijging van den doctorstitel. Wel is zij opgedragen aan verschillende aanzienlijke en hooggeplaatste mannen, aan den curator THEODOOR VAN WELDEREN, den burggraaf JOANNES vaN WELDEREN, den professor en vader Petrus de Greve, den oom Willem de Greve en aan de bloedverwanten Thomas Pels en ENGELbert Bongart, maar toch ontbreken die bekende woorden pro gradu doctoratus etc. En wat merken wij verder op? In I675 is deze ALBERTUS ingeschreven te Leiden en in 1676 promoveert hij te Franeker met een disputatio de foro competenti, het boekje, dat als No. 7 staat opgegeven.

1) Zeer te betreuren is het, dat waarschijnlijk verloren ging de levensbeschrijving, die TEIt.ER zelf opstelde. Zie 'Th. L. Roukens, Oratio de Acalemia Noviomagensi, 1769, p. 20 : „viri hujus, sanequam eximi, commenta:ia de vita sua asservantur in paterna biblotheca. 
Ook dit werd te Nijmegen gedrukt en geraakte daarom in de Amhemsche collectie verzeild. Ik behoef bijna niet te zeggen, dat wij op No. 7 kunnen lezen, hoe het den student te doen was om den graad van doctor.

Hetzelfde is het geval met No. 17 en I 8, welke boekjes tot schrijver hebben J. VerbolT Grollanus. No. I 7 is een disputatio uit Nijmegen van $167 \mathrm{I}$, maar

- No. 18 is de disputatio inauguralis pro gradu doctoratus, te Leiden gehouden in het jaar 1674 .

Het spreekt van zelf, dat ik ook de namen der overige studenten opzocht in de lijsten van Leiden en Utrecht. Verscheidene dezer namen vond ik terug te Leiden. BORs, CraElvaNGer en Wentholt begaven zich spoedig na het houden van hun disputatio naar deze bekende universiteit. De eerste van dit drietal, JOANNES BORS, promoveerde er met een dissertatie ,de societate", van de beide andere studenten vond ik niets. Misschien vertrokken eenigen naar Harderwijk. Daar mij echter onbekend is, of een volledige opgave van de studenten te Harderwijk soms in manuscript bestaat, kon ik dit niet nagaan. Over No. I IsAAC VAN DEN BERGH valt ten slotte nog dit mee te deelen. Hij was de zoon van LAURENTIUS VAN DEN BERGH, burgemeester van Nijmegen en curator van de academie. Zijn disputatio is aan verscheidene personen opge. dragen, o. a, aan den professor primarius PETRUS DE GREVE en den professor ordinarius GERARI NOODT, terwijl achteraan een vers volgt: In honorem ISAAC. VAN DEN BERGH, quaestoris in hac civitate vigilantissimi. Aangezien deze student reeds de betrekking vervulde van quaestor, d. w. z. rentmeester, dat hij zijn disputatio hield, zal hij zeker de noodzakelijkheid niet gevoeld hebben om naar Leiden te gaan en een titel te behalen, die overal in den lande erkend werd. Hij liet derhalve in 1674 , het jaar van zijn disputatie, zijn broeder, over wien wij te'voren spraken, alleen vertrekken.

De slotsom is dus deze. Inderdaad zijn er te Nijmegen enkele studenten gepromoveerd, maar de meeste zagen in, dat het veiliger was hun titel elders te behalen, waaronder ook zonen van professoren en magistraatspersonen ${ }^{1}$ ). Ongetwijfeld werd de titel behalve te Nijmegen als ongeldig beschouwd.

Wie wil weten, hoe noodlottig de jaren I672-1674 voor Nijmegen zijn geweest, leze het belangrijke artikel van vax Schevichaven in de "Penschetsen uit Nijmegen's verleden"'2). $\mathrm{Na}$ een hardnekkige verdediging, waarbij I 300 Franschen gewond en r IOO gesneuveld waren, begon de gouverneur VAN WELDEREN met den vijand te onderhandelen, met dit gevolg, dat 12 Juli het Fransche leger

1) $\mathrm{Bij}$ een onderzoek te Leiden bleek $\mathrm{mij}$, dat ook twee zonen van den syndicus Van SOMEREN, die zijne gedichten de academie en alles wat er mee samenhing bezong, in $\mathbf{1} 6$ \%o te Leiden in de rechten promoveerden. ) H. D. J. van Schevichavex, Penschetsen uit Nymegen's zerleden, p. I $8-$ I $_{3} 6$. 
onder aanvoering van TURENNE binnentrok. Behalve de groote sommen, welke men aan de Franschen moest betalen voor onderhoud, drukten nog andere lasten op de stad. Het bombardement van uit het fort Knodsenburg had veel schade aangericht, kerken en openbare gebouwen hadden zeer geleden, en thans na de overgave was men genoodzaakt deze schade zoo spoedig mogelijk te herstellen. Niet alleen de stad, maar ook de particulieren hadden het hard te verantwoorden. $\mathrm{Zij}$ die uitgeweken waren werden, tegen de voorwaarde van overgave, zwaar beboet, en zij die bleven gingen gebukt onder inkwartiering en geschenken van allerlei aard. Ware de gouverneur, Graaf DE LORGES, meer te Nijmegen aanwezig geweest, waarschijnlijk zouden de Franschen niet zoo wreed huis gehouden hebben, beter lettende op de artikelen der capitulatie; maar door zijn voortdurende afwezigheid kregen de commissaris Méthelét en majoor de ST. MARTin, twee mannen zonder gevoel en geweten, de handen vrij en mergelden de bevolking uit. In deze moeilijke dagen stond het onderwijs stil, te meer daar in de zalen van de academie Fransche soldaten gecaserneerd werden. Op den dies natalis van $1672^{1}$ ) had men nog volgens gewoonte den feestelijken maaltijd gevierd en op stadskosten IOg gld. 12 st. verteerd; GFRARDUS NOODT J. U. D. „van goede studie en reputatie", op het laatst van het vorlg jaar tot tweede professor in de Rechten benoemd, werd nog in Januari feestelijk onthaald; maar het waren de laatste teekenen van leven, de academie sliep langzaam in. $\mathrm{Na}$ het vertrek der Fransche legers heeft de Raad herhaaldelijk pogingen aangewend om den bloei en luister van vroeger te herstellen, evenwel zonder gevolg, want de medewerking van het Quartier en de geldelijke middelen ontbraken. Wij zullen in de volgende bladzijden zien, dat al wat de Raad deed om de belangstelling weer aan te wakkeren, afstuitte op het gebrek aan geld en op de moedeloosheid van velen, die jaren lang meegestreden hadden voor het goed recht der Nijmeegsche academie, maar nu na de bezetting der Franschen het hoofd lieten hangen.

In het jaar 1673 melden noch de raadsignaten noch de rekenboeken iets over de academie. Men had het te druk met de onwelkome gasten. Wij kunnen met groote zekerheid zeggen, dat geen onderwijs gegeven werd uit gebrek aan collegezalen en studenten. Paaschmaandag 30 April trokken de Franschen weg ell werd de oranjevaan op den toren geheschen. Nijmegen was vrij en de Raad mocht weer $z i j n$ tijd besteden aan het welzijn van de aan hem toevertrouwde stad. Met loffelijken ijver werden, gelijk de rckenboeken ons bewijzen ${ }^{2}$ ), maatregelen

1) Roukens, 1. 1. p. 2z. Hoc difficillimo tempore clarissimus SAMUed Tenulius tertio nonarum Maji, instructissimo cum exercitu licet urbi jam immineret hostis, tamen rectoratu jam abiens orationem habuit: in laudem Guliani imperatoris.

2) Rekenboek 1674. „Aen Mr. Adriakn van DEN HAM betaelt sestien gl. tien stujij. voor arbeytsloon over 't repareren en herstellen van de professoren gestoelte in de Academie."

"Aen Mr. Adriakn van den ham en Carel Rampers i 8 gld. 6 st, voor hetzelfde".

Oud-Holland Igoo. 
genomen om het gebouw, waar de soldaten niets hadden ontzien, voor gebruik geschikt te maken; en opdat men aan de buitenwereld zou toonen, dat de academie nog niet was opgeheven, liet LAURENTIUS VAN DEN BERGI, curator van de universiteit, zijn zoon ISAAC weinige dagen na den aftocht der Franschen in het publiek een disputatie houden. Deze maatregelen waren gemakkelijk te nemen en gingen niet met groote geldelijke kosten gepaard, maar iets anders was het van de professoren te vergen, dat zij zonder tractement en zonder de emolumenten van vroeger hun geleerdheid den studenten zouden voordragen. De behoeften van kamergeleerden mogen gering zijn, met een hongerige maag is het niet mogelijk te werken of te doceeren. Vooral was dit ondenkbaar bij de professoren van dien tijd, die te Nijmegen even goed als te Leiden en elders het werken gaarne eens onderbraken voor een schranspartijtje. Rceds vóór 1672 waren er van den kant der professoren klachten opgegaan over het slecht uitbetalen der tractementen, en dat nog wel terwijl de Raad in het begin van 1655 vóór de opening cr voor gezorgd had, dat de professoren geregeld om de drie maanden hun geld kregen. Immers in het raadsignaat van $\mathrm{I}_{4}$ Februari lezen wij, dat de ontvanger en raadsvriend ARNOLD RAMPERs voor de schepenen VERBolT en CORNELII belooft een vierde van de subsidie, door het Quartier toegezegd, geregeld om de drie maanden te zullen betalen in handen der professoren, en het overschot te overhandigen aan den stadsrentmeester tot verdere onkosten voor de academie. Mocht e: een vertraging ontstaan in de betaling, dan behield de Raad zich het recht voor "die gereetste middelen vant quartier in der stadt ende schependom voorhanden weesende" te aanvaarden en te lichten. In het uiterste geval kon de Raad de particuliere goederen van den ontvanger executeeren. Gedurende de eerste jaren greschiedde de betaling vrij geregeld, totdat in April I658 WitTiciulus en Schulting te vergeefs op het laatste kwartaal wachtten en hun noodklaagden. Om er den schrik in te brengen, liet de Raad den ontvanger aanzeggen, dat hij binnen zes dagen had te betalen, of dat hij anders door de stadsdienaren in zijn huis geëxcuteerd zou worden. Op het woord volgde de daad, maar omdat RAMPERS de belofte deed binnen veertien dagen uit te betalen, hief men de executie op '). Deze laatste moeilijkheid en het feit, dat reeds vroeger nu en dan klachten vernomen waren, deden den Raad op 26 Mei 1658 besluiten, dat de betaling voortaan moest geschieden uit den bieraccijns. Een der pachters betaalde aan de professoren het tractement uit, welke som de ontvanger in de pacht korttc en verrekende ${ }^{2}$ ). Zoo schijnt het gegaan te zijn tot het ongelukkige jaar 1672 .

1) Zie de raadsignaten van 3 I Maart, 2i en 23 April 1658.

2) Het archief van Nijmegen bezit een aantal dezer quitantiên van de jaren I663-r669. Eén haal ik: als voorbeeld aan:

Bekenne onderschreven van mr. Johıxxes KERKwljCk, pachter der accijnsen alhier, voor een vieren- 
Van dat oogenblik staakte de uitbetaling. De toga der professoren moest wijken voor de wapenen der Franschen. Met het aftrekken der vijanden hield wel de knevelarij op, maar zware lasten bleven drukken op Quartier en stad. Veel wat vernield was, moest hersteld worden, en weldra stonden nieuwe gasten, de gezanten der verschillende staten, voor de deur. Dit vredelievend bezoek, dat ongeveer twee jaren duurde, bracht groote onkosten mee en was een ware plaag voor de burgerij, nauwclijks bekomen van alle doorgestane ellende '). Het Quartier vergat de subsidie, zoodat op 28 September 1676 de raak in den Raad ter sprake kwam. „De Heer Burchgraeff WELDEREN - zoo lezen wij in het raadsignaat -- als curator der universiteijt binnen dese stadt ter vergad voorgedragen hebbende, dat de respective professoren nu vijff jaren geleden geene de minste betalinge van haar verschenen tractement hadden genoten en deswege redenen hadden om t'selve kiachtigh te kennen te geven, ende aldewijll de directie der betalinge van derselver tractementen altijt acn een Eerb. Raadt gespecteert heeft, worden oversulcx Haer Ed. en Achtb. versocht daerinne te willen continucren, ten eijnde voorsz. professoren eenige betalinge mochten erlangen, waarop gedelibereert sijnde, is goet gevonden te committeren de Heeren raedtsvrunden Singendonck en Waters om bij de Heeren Gedep.den deses $\mathrm{q}^{\text {rs }}$ aen te houden ende te bevorderen, ten eijnde opgemelte professoren mogen clachteloos werden gestelt.' Do heeren van het Quartier waren wat hardhoorig; en waar de Raad eerst begon met verzoeken en vragen, eindigde hij in October 1679 met dreigen. Het raadsignaat van 1679 luidt: „Een Eerb, raadt heeft de Heeren Gecommden SINGENDONCK en WATERS versocht om nogmaals de Heeren Gedeputeerden op het serieuste te recommanderen, dat de professoren wegens hare achterstedige tractementen cenichsints mogen werden gesoulageert, dat andersints Haer Ed. en Achtb. sullen genootsaeckt wesen om de hant in de middelen, daertoe voor desen gedestineert, te slaan." Evenmin als het Quartier er aan dacht de subsidie te geven voor het betalen der tractementen, zoo herinnerde het zich, dat het in I 657 vrijheid van verscheidene imposten had verleend. Op voorbeeld der andere academiën was de Raad hiermede begonnen, want op 29 April 1655 bepaalde hij, dat de professoren van stonde aan vrijheid zouden genieten in den bieraccijns. en dat na afloop van de loopende pacht, die 30 Juni eindigde, zij eveneens zouden vrijgesteid worden van den wijnaccijns, "ende dat voor soo veel sij in haere

\footnotetext{
deel jaars tractement, op clen isten November laatstleden verschenen, de somme van tweehondert en vijfentwintig gulden ontvangen te hebben.

Nieumegen den 2 November Aa 1668 .

Theon. CraAnen.

Deze 224 gld. heett de ontr. JONDAN mij in de pacht van de bieren laeten corten en goet gedaell.

1) H. D. J. van Schevichavex, Penschetsen wit Nijmeres's heriden.

joH.LXNes KrRCEWlgck.
} 
particuliere mesnagies van node sullen hebben" "). Daar de universiteit in bloci toenam en steeds door meerdere studenten bezocht werd, wilde het Quartier niet achterblijven, vooral toen de Raad een dergelijk verzoek deed. Ook van wege het Quartier werd aan de professoren vrijstelling van verscheidene imposten verleend. Dit alles scheen men vergeten in 1674. De Raad evenwel, die de academie boven water wilde houden, bemerkte dit nauwelijks, of bracht den heeren de oude belofte in herinnering. Immers in het raadsignaat van 30 Juni 1674 staat: "Met d'aenstaende verpachtinge van des quartiers middelen vernomen sijnde, dat de heeren gedepden d'exemptie van de professoren en studenten met vrijicheijt voorbij gegaen sijn, en alsoo d'universiteijt deser stadt tacite souden schijnen te willen discontinueren tot groote praejuditie deser stadt, is goet gevonden door de Heeren COERMAN en HEIJSEN op de verpachtinge op de voorsz. exemptie t'insteren, dat deselve als van outs moge gecontinueert worden ende daervan bij de Heeren Gedeputeerden aenteijckeninge in de notulen laeten maecken." Deze moeilijkheid heeft ongetwijfeld besprekingen uitgelokt. Kon men spreken van het bestaan der academie of niet? Dit was de vraag. Bij de nieuwe verpachting van I Juli ${ }^{6} 65$ kwam de Raad op de zaak terug en besloot in de vergadering van 30 Juni: ${ }_{n}$ Alsoo de verpachtinge nu aenstaende is ende de professoren in de bedieninge van de academie sijn herstelt, is goet gevonden met communicatie en approbatie van de Heeren Gedeputeerden ende de Heer Borchgraeff WELDERLN als curateur vant quartier, dat de voorsz. professoren haren tax en quota van exemptie in de bieren en wijnen weer sullen genieten als van outs, en t'selve bij de verpachtinge bekent te maecken."

Wat voor moeite de Raad ook deed, de academie leed een kommervol bestaan. Het college van professoren was niet voltallig; aan nieuwe benoemingen werd evenwel niet gedacht. Ja zelfs reeds voor de komst der Franschen was men overeengekomen om CHRISTOPHORUS WITTICHIUS, professor in de theologic, die naar Leiden vertrokken was, niet meer te vervangen ${ }^{2}$ ). Gebrek aan gel $]$ en waarschijnlijk ook gebrek aan theologische studenten dreef den Raad hiertoe. De professoren; die in 1674 zich nog te Nijmegen bevonden, waren:

PETRUS DE GREVE, professor primarius in de rechten ${ }^{3}$ ).

1) Voor de studenten was ook gezorgd. Zij hadden vrijstelling van accijns voor een half vat bier per maand en een aam (4 okshoofden) wijn per jaar.

2) Zie het radsign. van 27 December 1670.

3) Petrus de Greve, van den beginne af aan de academie werkzaam, stierf te Nijmegen op het laatst van 1677 . Zijn graf is te vinden in de Groote kerk en op den grafsteen staat:

Viri clarissimi PECRI DE GREVE Juris consulti et per annos I et XXX antecessoris quidquid mortale fuit Hic situm est. Obiit Prid. Kalend. Januarii MDCLXXVIII. Vermeld wordt een „Oratio funebris in $P$. DE GReve" van Gerard NoODT, die ik niet te zien kreeg. 
GERARD NoOdT, professor ordinarius in de rechten ${ }^{1}$ ). Samuel Tennulius, professor in de historie en welsprekendheid ${ }^{2}$ ). Thomas Pels, professor in de medicijnen ${ }^{3}$ ). JoAnNes TEILER, professor in de mathesis ${ }^{4}$ ).

Van het Quartier kon men weinig steun verwachten, zooals wij zagen, en Caarom nam de Raad een ander middel te baat. Hij wendde zich tot WiLLEM III, prins van Oranje. De voorvechters van de Harderwijksche academie zaten echter mede niet stil, ook zij zochten den Prins te winnen voor hunne belangen, en traden ten slotte na jarenlang met Nijmegen gestreden te hebben, uit dit gevecht als overwinnaars te voorschijn.

WILLEM III werd in Februari 1677 in Gelderland verwacht om de regeering: vast te stellen. Terstond benoemde de Raad een commissie, bestaande uit de HH. FaGel, CoERman, Verheiden en den raadssecretaris Klerck, opdat zij hun zaak bij den Prins zouden bepleiten en alles aanwenden „om de provinciale academie hier binnen Nijmegen te vercrijgen." Heel veel resultaat heeft dit niet opgeleverd, want 23 Januari 1677 bepaalde de Raad, dat de gecommitteerden ter Landdage cenige punten ter consideratie zouden opstellen omtrent de academie te Nijmegen. Het plan was dit stuk aan Z. H. voor te leggen. Het Quartier bleef alle krachtdadige hulp weigeren; verscheidene der gedeputeerden beschouwden het een hopelooze zaak, te meer daar niet onduidelijk bleek, hoe de Prins zich schaarde aan den kant der voorstanders van Harderwijk. Zelfs kwam er I5 Mei 1678 een advies in van de buitengewoon-gecommitteerden en gewoongedeputeerden ${ }^{5}$ ), behelzende den raad om de academie op te zeggen en te

1) Gerard NoOd maakte 28 Februari I679 aan den Raad zijn beroep naar Harderwijk bekend. 4 Augustus kwam hij nog eenmaal in den Raad, ten einde een zaak te vereffenen. Wij lezen daar: „GERARD NOODT binnen staende en van sijn E. tractement (van de Heeren Gedeputeerden geassigneerd op 't familiegelt) ten achteren sijnde een somme van $85^{\circ}$ gulden, versosckende betaelinge, waarop gedelibereeri, Is verstaen, dat men sijn E. Sal doen hebben contentement en sijn daer toe geordonneert de coopspenningen van seecker clein huyske aen de Nieuwstraet gelegen, bij Diderich Sweers aengecoft."

2) SAmuel Tennulies, schoonvader van Groxorius, hield zijn inaugurale rede, de Belgarum fortuna et eorum cum Romanis comparatione" op $\mathbf{I}_{4}$ Januari $\mathbf{1 6 6 \%}$. Voor het transport van zijn meubilair van Steinfurt naar Nijmegen kreeg hij 250 guiden.

3) Wij hebben pag. I59 gezien, dat THomas PELs tegelijls met 'ohannes TeILER in I67oopvolger werd van Cranen. Reeds vroeger lezen wij den naam van PELS in de raadsignaten met betrekking tot de academie. Begin Januari 1660 richten de doctoren Thomas P'els en Gualterus de Mandevillis aan den Raad hei verzoek; of zij naast professor EMANUEL DE MANDEviLle de geneeskunst mochten doceeren zonder tractement. De Raad had bezwaren tegen PeLs, omdat hij geen lidmaat van de Gereformeerde kerk was.

4) Over TEILER is boven pag. I59 uitvoerig gesproken.

5) 30 April had het Quartier Johan van Gent tot Winssen, Diderick van Els en Wilt van BroeckHUijSEN uit de ridderschap en CoenraAd, SINGENDONCK, burgemeester van Nijmegen, Johan Biell, schepen van Tiel en Johan van Cockengen, schepen van Bommel uit de steden benoemd, ten einde het Quartier van het advies te dienen over de geidelijke toestanden. Hun advies luidt: "De extraordinarise gecommden en ordinarise gedeputeerden hebben tot voldoeninge van UEd. Mog. resolutie van den 30 Apsil overwogen en serieuselijck geëxamineert de poincten daer inne vervat, omme deses Quartiers finantien door t' verbeteren ende 
"mortificeren" on een overcenkomst te sluiten met de professoren. Nog hieid de Raad vol; 9 December 1678 gingen de burgemeester SinGENDONCK, de schcpen WATEES, de raadsvrienden ROMSWINCKEL en DE BEIJER, benevens de sccretaris FRLdeRICK VAN Helckelom naar Den Haag. Hun opdracht was, bij Z. H. al hun best te doen, dat de Illustre School te Nijmegen mocht gecontinueerd worden. Een volgende poging dateert van 28 Juli I682. Men wist, dat de Prins te Dieren was en daarom gemakkelijk te bereiken. Burgemeester FAGKi. werd verzocht de gecommitteerden van het Quartier bijeen te roepen om te beraadslagen, of men een schriftelijke deductie over de academie bij Z. H. zou indienen. Deze deductic stuurde men eerst twee jaar later naar Den Haag, toen de kansen voor Harderwijk steeds beter stonden. Te voren hadden de Raad cn vooral het Quartier hun tegenstander te licht geteld, maar thans bang geworden, stelden zij alles in het werk. De Raad had zich slechts weinig te verwijten, het Quartier des te meer. Had het Quartier den Raad gesteund door de subsidie, waaruit de professoren werden betaald, niet in te houden, misschien zou de toeloop van studenten, rrelijl: vóór 1672, na 1674 teruggekeerd zijn en in dat geval zou het groote contrast tusschen de vervallen academie van Harderwijk en de blociende universitcit to Nijmegen zeker den Prins voor Nijmegen gestemd hebben. Nu kreeg Harderwijk den steun van den vorst, omdat het de oudste rechten had ').

Waardoor werd het Quartier plotseling wakker en vol ijver voor de goede zaak? Met de herleving van de academie van Harderwijk ging natuurlijk gepaar $d$ de jaarlijksche bijdrage der dric Quartieren. In de moeilijke jarcn, waarin de vijanden het land verwoestten en handel en nijverheid belemmerden, was over betaling nict gesproken. Nauwelijks was men weer eenigszins op zijn verhaal gekomen en waren de verwarde geldzaken zoo goed mogelijk geregeld, of daar klopte Harderwijk aan met de vraag, of het Quartier, zooals vroeger, jaarlijks 2800 gsulden wilde bijdragen tot instandhouding van de academie. Dit beviel aan het Quarticr gecnszins Het had den Raad van Nijmegen zich van den hals geschoven; op dezelfde wijze trachtte het zich te onttrekken aan het verzoek van Harderwijk en het Quartier der Veluwe. Kras liet men zich uit, toen het Quartier der Veluwe op de vergadering van den Landdag had voorgedragen om in conferentie te komen tot het herstcllen der academie. Ilet Quartier van Nijmegen oordeclde het $29 \Lambda$ pril 1684 volstrelt niet noodig een conferentie te houden,

beneficeren van de ordinarise en extriordinarise of introductie var nieuwe middelen, soo veel doenlijk, te hetstellen - hebben goetgevonden ULd. Mog. bij forme van praeadvijs voor te brengen dese navolgende consideratiên: Dat de Academie off universiteijt tot Nijmegen bchoorde opgeseijt ende gemortificeert te worden, met asuthorisatie aen de ordinarise zredepden omme met de professoren, alnoch in leven sijnde, of der overieder:

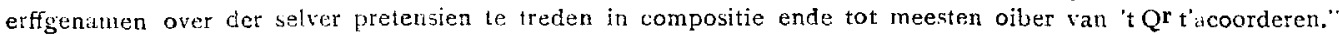
1) Zie Boumas, (ieschietenis alu de zoomalige Geldersche Hoogeschool. 
daar sedert lang de academie te Harderwijk voor onnut was verklaard. Werd er in den Landdag weer over gesproken, dan moesten de gecommitteerden niets besluiten, alvorens zij het Quartier gehoord hadden. De brief van den Stadhouder werkte niets meer uit, zooals blijkt uit het reces van I4 Januari I685: "mgelesen eene missive van sijne Hoogh. geschreven in 's Gravenhage 18 deser N.S. heeft het quartier goedgevonden, dat aen Z. H. zal worden gerescribeerd, dat zij geene redenen hebben connen vinden, waeromme van vorige Lantschaps resolutie, waerbij d'academie aldaer is inutil verclaert, zoude worden affgetreden, maer goed gevonden daerbij te persisteren. ELS en VERBOLT versocht ende gecommitteerd om sijne Hoogh. van de solide redenen en motiven naerder openingh ende omstandigh bericht te doen". Noch WILLEM III noch'Harderwijk lieten het Quartier met rust. Ook al werd "in beleefde en serieuse termen" aan den Stadhouder geantwoord, dat men voor alles orde moest stellen op de vervarde finantiën en hem later door eenige gecommitteerden nader bericht en informatie zou worden gegeven, het hielp niets. Wel werd de zaak op de lanue baan geschoven, maar dit was ook het eenigste, wat men bereikte. De brief van Willem III, waar de heeren zoo serieus en beleefd op antwoordden, dagteekent van 9 April I686 N.S. Een verzoek van de gecommitteerden der stad Harderwijk kwam in het Quartier van Nijmegen ter sprake op 20 Mei en een ancler van het Quartier der Veluwe op 6 November. Hoe weinig voortgang achter de zaak zat, zien wij uit het reces van 17 November van hetzelfde jaar, waarin staat: "Gehoort het rapport van den amptman WFLDEREN en andere gecommitteerden ingevolge van derselver resolutien commissoriaell in datis 26 Mei en 6 November 11. raeckende de praetense herstelling van de academie tot Harderwijk, Ende dienvolgens nader gedelibereert over de missive van $Z$. H. aan haar Ld. Mos. scschreven tot Dieren in dato 9 April, waerbij hij verclaert te sullen verwachten, dat dit quartier eindelich sal resolutie nemen tot het behoorich furnissement van de oncosten en lasten van een provinciale academie tot Harderwijk, met dese bijvoeginge, dat bij verder dilay niet soude connen ledigh staen tot soodanigen einde te emplojeren den wegh en het middel van decisie, Is goet gevonden en verstaen te committeren ende te versoucken VAN EIS en VERBOLT, gecomm. van haer Hoog Mog. uyt dit quartier, om Z. H. nader te berichten en informatie te geven." Zij kregen een instructie mee. Mocht het zijn, dat $\%$. H. de redenen, waarom men tegen een herstelling dezer academic was, op schrift wilde hebben, dan werden zij geauthoriseert om door een bekwaam persoon, ,de voorsz. redenen en motieven nae de gewoonlicke behoorlicke stijll te doen dresseren en schriftelick ter neder te stellen en aan Z. H. ter fine van informatie over te geven." Do aanhouder wint; door te kloppen op hetzclfde anoceld bereikte het Quartici 
van de Veluwe het gewenschte doel. Toen op 7 Mei 1687 bij het Quartier van Nijmegen het verzoek kwam, of men zich wilde uiten en verklaren over de restauratie van de academie, werd goedgevonden, dat door eenige leden uit de verschillende Quartieren een conferentie werd gehouden „op rapport ijder aan sijn quartier." Dit was een schrede vooruit, doch ook niet meer. I4 Mei I687 verschenen de gecommitteerden van het Quartier der Veluwe, de landdrost Licas Willem van Essen, de richter Johan van ARnhem en de burgemeester AdoriaAN Menthens op de vergadering van het Nijmeegsche Quartier en verzochten, dat men, alvorens in conferentie te treden, het besluit tot afschaffing zou intreliken en genegen zou zijn in het vervolg van tijd de vroegere subsidie te continueeren. Het Quartier weigerde hardnekkig. 7 Juni 1687 kwamen eenige gecommitteerden uit de Veluwe over voor de conferentie. Enkele dagen te voren had men eene missive van den Stadhouder ontvangen, waarin de herstelling ernstig werd annbevolen. Niettegenstaande dit verzoek van hooger hand kregen de gecommit. teerden van het Nijmeegsche Quartier de opdracht, "dat aen de gecommitteerden van de Veluwe soo veel doenlick met alle meest crachtige redenen, motiven en allegaties van vorige genomene resolutien sullen voordragen en sooveel doenlick deselve trachten te persuaderen, ten einde wegens t'quartier van de Veluwe geene verdere instanties tot herstellinge van deselve academie behooren gedaen te worden, op rapport aen t'quartier." De conferentie werd gehouden op 9 Juni, en op I I Juni brachten DIDERICK vax ELs en de andere gecommitteerden hun verslag uit in de vergadering van het Quartier. Het verzet was gebroken; vooral de ernstige woorden van den Prins maakten, dat men het hoofd boog en besloot, dat jaarlijks 2800 gulden subsidie aan Harderwijk zou worden gegeven, mits het Quartier van de Veluwe niet terugkwam op den achterstand van de laatstejaren. Beloven en betalen zijn twee. Tot I69 I scheepte men Harderwijk af met het argument, dat de oorlog alles verslond, en met moeite wisten de heeren van de Veluwe op 2 December gedaan te krijgen, dat, zoo niet de volle som, toch iets werd bijgedragen; I 200 gulden beloofde het Nijmeegsche Quartier. Volgens de quartiersrecessen kwam de zaak 1722 geheel in orde en bedroeg de subsidie voortaan weer 2800 gulden.

Door het herstel der Harderwijksche academie verdween alle hoop opeen heropening van de Nijmeegsche. Deze instelling, zoo feestelijh op 3 Mei 1655 geopend en zoo snel in bloei toegenomen, verliep na 1672 gaandeweg. De promotie van ABRAHAMUS VAN SENDEN op i2 Februari 1678 zal, dunkt mij, niet vroolijk geweest zijn. Professoren, studenten en belangstellenden moeien het gevoel gehad hebben, alsof zij ter begrafenis gingen en grafwaarts droegen iets, wat hun eenmaal dierbaar was. Aan uitputting van krachten was het kindje 
gestorven. Evenwel kon men met trots neerzien op het eerste vijftiental jaren. Door geen kosten te sparen, geen moeite te ontzien lokte de Raad vele knappe professoren hierheen; en waren zij met ijver werkzaam, dan werd alles gedaan om hen hier te houden. Zoo bijv. verhoogde de Raad het tractement van DE GREvE met IOO gulden, toen hij bedankte voor het beroep van professor primarius te Groningen ${ }^{1}$ ). GUalterus dE MANDeville, in Februari $166 \mathbf{I}$ opvolger van zijn vader Emanuel als professor in de medicijnen, krijgt 200 gulden om een reis naar Parijs te maken en daar ongeveer een jaar de gasthuizen te bezoeken. Aan Professor CRAANEN, die als opvolger van SOUDAN de philosophie zou doceeren ${ }^{2}$ ), werd toegestaan eenige globen in te koopen ten gebruike bij het onderwijs. Hij besteedde hiervoor 208 gld. I 8 st. Wij kunnen ook nog wijzen op de bereidwilligheid, waarmee de Raad de stadsbibliotheek aan de universiteit afstond en meewerkte tot vermeerdering van het aantal boeken. Op 23 Maart I659 besloot men de magistraten, gedeputeerden, professoren en predikanten te verzoeken om een goed boek uit hunne verzamelingen voor de bibliotheek af te staan, opdat dit ten goede zou komen aan de studeerende jongelingschap. Doch genoeg, uit deze enkele voorbeelden kunnen wij begrijpen, dat de stad veel voor deze instelling over had. Geen wonder dan ook, dat behalve een enkele uitzondering de professoren, die men beriep, begaafde mannen waren. De Raad behoefde niet aan te kloppen bij de dei minores, want daar de voorwaarden aannemelijk en de behandeling uitstekend waren, wilden mannen van grooten naam met genoegen komen. Ik behoef slechts de namen te noemen van WitTICHIUS, DE GREVE, SChulting en NoodT. Hunne werken, ook al hebben zij voor ons veel van hun waarde verloren, werden in die dagen met lof vermeld en ijverig gelezen, en behalve deze geschriften mag ook het feit, dat drie Nijmeegsche professoren naar Leiden verhuisden, gelden ais bewijs, hoe groot de roep was, die van hen uitging. Wittichius, de bescheiden en beminlijke Cartesiaan, om wiens bezit Nijmegen met Duisburg in 1655 moest vechten "), vertrok in 1670 naar Leiden; CRAANEN, die op vele markten thuis was en de wijsbegeerte, mathesis of

1) Zie de raadsign. van 24 Januari en 28 Januari $x 667$.

2) Over Soudan schreef ik uitvoerig in de Naverscher, I 899 en rgoo. Toen Wit TichiUs aan CRaANex geschreven had, of hij voor 300 rijksdaalders wilde komen, antwoordde hij, dat hij bereid was op te treden als "professor mathesius et philosophiae," mits hij ook in de medi ijnen mocht college geven. I Februari I66I beriep de Raad hem, maar met de bepaling, dat hij viermaal per week de philosophie zou doceeren; wat de andere vakken betrof, mocht hij doen zooals het 't best uitkwam. Voorloopig was het tractement 800 gulden. Bloeide de academie door zijn komst, dan was de Raad bereid de som te verhoogen. In 1666 was hij rector magnificus en kreeg op zijn verzoek een opslag van Ioo gulden.

3) Zie J. H. Writiofrus, Acta Sacrorum Academiae Duishurgensis. Duisburgi, 1756. De arademie te Duisburg werd I $_{4}$ October 1635 geopend. Wirtichius liep in den plechtigen optocht mee en kreeg voor alle moeite, welke hij roor de oprichting gedaan had, het doctoraat in de theologie.

Oud-Holland igoo. 
geneeskunde doceerde, trad in het voorjaar van 1670 als onderregent van het Statencollege te Leiden op; Noovt, leerling van de Apostolische school te Nijmegen en later van de academie, een groot jurist en waardig collega van DE. GREVE, hoewel nog geen 20 jaar oud, werd eerst geroepen naar Franeker, later naar Utrecht, en ten slotte naar Leiden. Een ander leerling van de Latijnsche school, Abrahay Gulichius, was slechts een korten tijd te Nijmegen professor. Drie jaar had hij op de schoolbanken gezeten en kreeg toen reeds het verlof van den rector de colleges der professoren te volgen, wat hij met zooveel ijver deed, dat de Raad meende hem geldelijk te moeten steunen. Hij ontving zelfs een extra bijlage om zijne studien te Leiden te voltooien ${ }^{1}$ ). Toen hij in December 1666 terugkwam en den Raad verzocht, dat hem werd toegestaan publice et privatim de theologie te mogen doceeren, stond men dit op aanraden van WiTtichiUs toe, mits hij niet rekende op eenig salaris buiten de subsidie, die hij nog 3 jaren mocht genieten voor het aanschaffen van boeken. Reeds in Januari van het volgend jaar kon hij den Raad mededeelen, dat hij tot ordinaris professor in de philosophie en welsprekendheid in Den Ham benoemd was tegen een tractement van $\mathbf{1} 70$ rijksdaalders 's jaars. Twaalf jaar later werd hij tegelijk met GERARD Noont te Franeker geinaugureerd, 6 October 1679. Mogen wij aannemen, wat Roukens zegt over den Waalschen predikant JOHANnes Braunius, dat deze n.l. de Hebreeuwsche antiquiteiten en Oostersehe talen te Nijmegen heeft gedoceerd, dan heeft ook Groningen een harer professoren uit Nijmegen gehaald. De zaak echter is mij niet geheel duidelijk. ROUkENs drukt zich zoo uit: "JoHANNes BraUnIUs studiosis in antiquitatibus Hebraicis et linguis orientalibus operam praestitit" 2). Hij schijnt werkelijk te bedoelen, dat BRACxils professor is geweest, iets wat ik niet kan gelooven. In de raadsignaten is niets van dien aard te vinden en zoo dikwijls als de magistraat met BRAUNIUS in aanraking kwam, lezen wij steeds ,Waalsch predikant." Hij was opvolger van Soudan in qualiteit van predikant, niet van professor. In Fcbruari $166 \mathrm{I}$ beriep men CRAANEx als

\footnotetext{
1) Raadsign. van 23 Januari 1661: „Op requeste van den quartiemeester van Gulick heeft een Eerbier Racdt om beweeglicke iedenen sijnen soon Aвraнam van Gultck, soo van Godt de Heer met een uytmuntent verstant ende memorie begaeft is. ende die sijne studien in corten tijt soo seer geavanceert ende voortgejet heeft, dat hij op d'academie alhier weinigh voordeel sal connen doen, bover bet beneficie van de Maricn.. xeertsche goederen, tot voortsettinge van sijne studien in d'academie van Leiden toegeleit 75 gid. 's jacrs." Het moet wel een bolleboos geweest zijn, dat de Raad hem weg liet trekken.

$\Rightarrow$ Roukess zegt t. a. p. nadrukkelijk, dat het gebelurde na clen dood van Soudan. Menso Isinck in i:jn , oratio funebris in obitum Johannis Braunir" drukt zich zoo uit: "similis ei provincia in Academia Noviomagensi post discessum cl. WiтTICHI ab illius urbis magistratu destinata est." De geleerden zijn bet nicz eens en de raadsignaten zwijgen. Juist uit deze stilzwijgendheid maak ik op, dat BrAUNius den titel van professor niet heeft gehad. Bij zijn beroep als professor naar Groningen verscheen hij twee malen in den $\mathrm{k}$ aad op 27 Augustus en op 28 October 1680 . Bij beide gelegenheden wordt hij genoemd ${ }_{n}$ Ds. JoH. Brulys, praedicant in de Walsche gemeente alhier". Geen woord over een professoraat.
} 
professor in de philosophie om Soldan te vervangen, en ro Februari van datzelfde jaar BRAUnits als leidsman voor de Waalsche gemeente. Misschien heeft RoukENs geen professoraat bedoeld, maar alleen willen vertellen, dat BRAUniUs ${ }^{1}$ ), later zoo bekend wegens zijn groote knapheid in de Hebreeuwsche antiquiteiten, te Nijmegen reeds de studenten voorthielp, natuurlijl zonder geldelijke vergoeding en zonder afzonderlijke benoeming van den Raad. Dit is mogelijk, hoewel ROUkENS geene bronnen aangeeft. De latere schrijvers over de Nijneegsche academie, die niet veel meer hebben gedaan dan Roukexs' woorden afschrijven, noemen BRAUNiUs professor; naar mij voorkomt, geheel ten onrechte. Het misverstand zal hieruit voortspruiten, dat BRAunics, een knap man, die in de geschiedenis van I672-I674 te Nijmegen een rol heeft gespeeld en ecn geschrift heeft gepubliceerd over de afpersingen der Franschen, SoLDAN als predikant opvolgde. Zonder de zaak behoorlijh te onderzoeken bevorderde Roukens hem tevens tot professor.

Natuurlijk was men niet altijd even igelukkig in zijn keuze. SoLDAN. Waalsch predikant en eerste professor in de philosophie, lict zijne boeken meer met rust dan de Nijmeegsche dienstmeisjes. De syndicus VAN SoMEREN moge de philosophische kennis van SOUDAN" nog zoo hoog opgehemeld hebben, toe: hij op het huwelijk van SOUDAN met SARA VAN BENTHEM een drietal gedichten makkte ${ }^{2}$ ), ik voor mij geloof, dat de Raad den dag, waarop deze satyr Nijmegen verliet, tot de dies fasti rekende. Ook ChristiaAs OTTER was hier niet op zijn plaats. Deze Pruis trad als professor op bijna zestig jaar oud. De Raad wilcle

1) Johannes Bratwius (Jean Brex) is de schrijrer van: "Le conseil dextorsion on la zolerie des Fra rois." Amsterdam, 1675. Van dit werhje zegt Domsfáler, die in zijn . Ontroerd Nederlandt" geheele stuklir: vertaalt: "een tractaet, waerdigh om van alle Naukeurige Liefhebbers van 't vaderlandt gelezen te worden:" In dit geschrift hekelt Braunius niet alleen de Franschen, maar ook enkele Katholieken, die met den vijanc! heulden. In I676 verscheen een klein boekje van GuIL. VolksT getiteld : "Le z'ray portrait du Polyphème de Nimigue alias fian Brun." Over dit allerinfaamste geschrift hebben wij deze twee raadsignaten:

24 Maart I676. Is bij een Eerb. raadt goet gevonden te verbieden $t$ ' vercopen van seecker boecxhen geint: le vray pourtrait du poliphème (BRAtNius was eenoogig) de Nimègue alias JEAX Bruyn, soo door onbekent persoon is gebracht ten huijse van ANTHONI ALBERTs boeckvercoper altier, ende die nogh onder den voorsz. boeckvercoper sijn, op $t^{\prime}$ raedthuijs te doen brengen, gelijck geschiet is.

29 Maart I676. Sijnde op klachte van D. JohAnNes BRCN, dienaer des goddelicken woorts in de Waltse gemeynte alhier, verlesen ende geexamineerr seecker boecxken onlangs in deze stadt gebracht onder den titel van Le vray portrait de Poliphème de Nimègue alias JEAx BRUN, heeft een Eerb. Raedt verclaert $t^{\prime}$ selve boecxken te sijn een fameus libel ende dienvolgens de HH. Borgemeesteren versocht ex officio te willen inquireren nae den autheur van $t^{\prime}$ selve boeckken, mitsgaeders nae die geene, de welcke $t^{\prime}$ selve in dese stad: gebracht off doen brengen hebben om tegen deselve te procederen tot sodanige straffen en boeten als nile gemeene rechten ende statuten deser stadt op d' autheurs ende propulateurs van pasquillen ende fameuse libellen sijn gestatueert.

In de "Politycque Ordonnantie" achter de raadsignaten van 1660 vinden wij dit artikel: "Die fameuse libellen, pasquilhen ende gedichten uitstrooit en daarvan overtuigd word, zal als infaem gebannen worden ende bovendien eene breucke geven van 200 golt-guldens."

2) Zie J. v. SOMERex, Uti-Spanning der Verruften p. 399. 
in 1657 gaarne een professor hebben in de mathesis, opdat alle vakken te Nijmegen door professoren zouden vertegenwoordigd zijn, maar het mocht niet te veel geld kosten. OTTER, die vecl gereisd had en in Holland onderricht in de vestingbouwkunde had gegeven, bevond zich te Arnhem, zoodat de Raad hem gemakkelijk kon laten vragen, of hij genegen was tegen een tractement van Ioo zilveren ducatons onderwijs te geven in de wiskunde ${ }^{1}$ ). De bejaarde man liet zich verleiden, maar heeft de twee laatste jaren van zijn leven zeker niet rustig en ongestoord doorgebracht. Wanneer wij JöCHER mogen gelooven, had OTTER in sterke mate de zonderlinge gewoonten van een man, die alleen voor zijn studie leeft. Hij was menschenschuw en in tegenstelling van SoUDAN een vrouwenhater. Bij zijn werk vergat hij alles. Is het wonder, dat de Nijmeegsche straatjeugd, die dagelijks zich vermaakte op de academieplaats, OTTER naliep en uitjouwde, wanneer hij het gebouw verliet. De Raad nam terstond maatregelen en verbood het spelen met kooten en het schieten met den kloot in de buurt van de academie ${ }^{2}$ ). Afdoende is dit echter niet geweest. Gelukkig stierf hij spoedig; in Augustus 1660 begroef men hem in de groote kerk ${ }^{3}$ ).

$\mathrm{Na}$ de professoren komen de studenten aan de beurt. Wanneer ik eens opschreef de namen der studenten, welke ik uit allerlei gegevens bijeen zoclit, zou menigeen verbaasd staan over het groot aantal, omdat hij zich den toeloop naar deze betwistte universiteit niet zoo belangrijk had gedacht. Hoe zijn deze namen mij bekend geworden? Voor een groot deel uit de raadsignaten, waarin zij meestal niet ter sprake komen wegens hun bijzondere deugdzaamheid. Wij zagen in de ordonnantie van $1659^{4}$ ), dat de mindere delicten door den academieraad afgedaan werden, de grootere door den Raad. Welnu de studenten gedroegen zich in de $17^{\text {de }}$ eeuw, nies alleen te Nijmegen maar ook in de andere academiesteden, zoo baldadig en woest, dat de Minervae alumni van heden er kinderen bij zijn. $Z_{i j}$ lieten het niet bij schellen moeren, nachtkabaal maken en ruiten ingooien, maar trokken hunne degens, sloegen vuur uit de straatsteenen, molesteerden fatsoenlijke menschen en vochten herhaaldelijk met de soldaten van het

1) OTTER heeft niets gesehreven, maar heeft ongetwiifeld een goeden naam gehad op wiskundig gebied. Dit blijkt bijv. uit de voorrede van Frasc. vas Schooren, Exercitationes mathemathicae L. IV. Hij verwondert

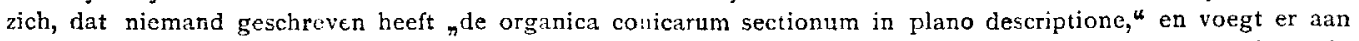
toe: ${ }_{n}$ novi ingeniosissimum virum O'TTERUM multa supee bac re excogitasse, sed neque ille, quantum innotuit, publici juris quidquam fecit."

2) Zie de raadsign. van 23 en 24 Februari 1659 ,

3) Roukens, 11. p. 16: "Sepultus est in choro templi majoris, ubi monumentum ejus cum epitaphio in tabula aenea, additis ab ipso novorum inventorum delineitionibus, etiamnunc prostat," VAN DER Mefr VAN KUFFELER heeft dit klakkeloos overgenomen, hoewel er op den huidjgen dag niets meer te vinden is in het koor van de kerk.

4) Zie pag. 3 . 
garnizoen. Een enkel voorbeeld $z \mathrm{ij}$ voldoende. Wij slaan op het raadsignaat van I 2 Februari 1663 en lezen daar: „Een Eerbaer raedt gesien ende geexamineert hebbende seeckere informatie, genoomen over het quaet tractement, soo JAN CLothier student in de Academie alhier neffens andere seecker Fransman, die in den Toelast, ten huise van JAN LAMER, gelogeert ende van daer bij nacht in het naeckte hembt door seeckere apprehensie op straet gecomen was, door gewelt met sijnen degen niet alleen op straet maar oock int huijs van STIJNEKE SEURMONT heeft aengedaen; Ende gelet, waerop in desen verder te letten stonde, heeft welgemelten raedt, nae rijpe examinatie van saecken, den voorsz. CLOTHIER over sijn begaene exces gecondemneert in eene amende van 250 gld., die hij gchouden sal sijn voor sijne relaxatie in contante penn. effectivelijck met de costen van dien af te leggen en betaelen." Gelukkig bescheen het licht van straatlantaarns dit nachtelijk tafereeltje niet. Onder de vrienden, die meehielpen, bevond zich JAN TOEBAST, zoon van een predikant. Hij werd voor 150 gụlden beboet. De straf schrikte hem niet genoeg af, want 7 April is hij er weer met vrienden op uit en gedraagt zich zoo moedwillig en insolent den geheelen nacht cloor, dat de Raad hem niet alleen straft, maar tevens het volgende besluit: "om eenen vasten voet in het toecomende int' stuck vande coercitie van dusdanighe moetwillighe studenten te houden, zijn bij een Eerbaer raedt gecommitteerd de raedsvrindt Dr. Willem Water met den secretaris Dr. CoenraedT KLERCK, omme te coomen in conferentie met den rectore magnifico ende de retroacta naegesien sijnde soodaene distinctie van coercitie en jurisdictie met de academieraedt te beraemen, als oordeelen sullen ten meesten dienste van de stadt en de Academie te behoren, alles op rapport ende approbatie van een Eerbaer Raedt." Meerdere voorbeelden zijn aan te halen, echter laat ik het hierbij, verwijzende naar hetgeen Dr. J. S. VAN VEEN heeft geschreven over het studentenleven te Harderwijk ${ }^{1}$ ).

Uit eenige bepalingen van den Raad maken wij op, dat velen zich als student lieten inschrijven, zonder het plan om te studeeren. De voordeelen aan het student-zijn verbonden, zooals vrijdom van accijns op bier en wijn, de vrijheid, die men als student had, om eens uit den band te springen, lokten velen, terwijl wij niet moeten vergeten, dat een lastig toelatingsexamen nog niet bestond. De Raad had het niet begrepen op die studenten a non studendo en keurde de maatregel goed, dat niemand uit de triviale school tot de academie zou toegelaten

1) Zie J. S. van Venn, Vit de witwendige en inwendige geschiedcnis dor voormalige Geldersche Hooge School. Gelre I898, Deel I, bl. I-70. 
worden tenzij op attest van den rector $\left.{ }^{1}\right)$. Dit gaf tenminste eenigen waarborg. Later tijdens het rectoraat van SAMLEL Tennulius in 1672 besloot de Raad. dat de rector magnificus geen acte van vrijstelling der accijnsen moch geren behalve aan hen, die werkelijk studeerden en goed college hielden. Met dergelijke: maatregelen voorkwam de Raad niet alle baldadigheden. Boeten moesten onophoudelijk opgelegd worden, zoowel door den Raad zelf als door den academieraad. Uit het geld dezer boeten kregen de professoren op i 8 Februari 1663 verlof eenige „juristen" aan te schaffen voor de bibliotheek; de burgermajoor DIRK DE MAN en de onderschout ontvingen ieder een gratificatie van 50 gulden voor - de moeite van het arresteeren en orde houden, terwijl stad en armen de rest (deelden. Toen in Augustus van $166_{3}$ eenige studenten den Waalschen predikant GALLli uit Zierikzee in het logement, het Hert" hadden geaffronteerd en mishan. deld, waren weer zware boeten gevallen, en wist de Raad er 26 September niets beters ol dan aan Heeren Curatoren der academie een gouden penning aan te bieden ter waarde van 100 gld. ieder. In het curatorium hadden de twee burgemeesters van Nijmegen zitting $\left.{ }^{2}\right)$. Daar nu ieder jaar twee nieuwe personen voor dit ambt werden gekozen, vond de Raad het billijk, dat voortaan alle burgemees. ters op een medaille of op een daarmee in waarde overcenkomende som geids mochten rekenen. In het raadsignaat van $2 \mathrm{I}$ Augustus ${ }^{6} 66_{5}$ hooren wij nog iets over deze penningen. De goudsmid JeLis VERHEYden had er acht vervaardigd. Daar nu de laatste twee voor de burgemeesters LEEUwers en VAN LENNEP de beste waren, werden de zes overige aan hem teruggegeven, opdat hij hen zou maken „van dezelfde forme, valeur ende curieusheyt" 3). Menig vader zai gezucht hebben onder de boeten van zijn zoon en geklaagd hebben over het dure studentenleven, maar waar de Raad in dit opzicht streng en hardvochtig was, stond hij

1) De bepaling staat in een ordonnantie op de Apostolische school en luidt: „Dat nieinant wt de triviale schole tot d'academie geadmitteert sal worden, als naedat den professor magnifico vertoont sal sijn attestatie van dcn rector van de triviale schole, waerbij dat bleecke den selven wt de triviale schole tot de academie gcpromoveert te sijn."

2) Behalve de twee burgemeesters waren twee gcdeputeerden van het Quartier curator. Deze curatoren werden benoemd voor een tijd van drie jaar, nnaer omganck van die weicken anderen in derselver plaetsen gesurrugiert sullen worden." Zie het quartiersreces van 10 Februari I $_{54}$.

3) Zoover wij weten, is één penning bewaard yebleven. De beschrijving is te vinden bij NAHUIJs, Médailles et fetons inedits relatifs à l'histoire des dix-sept anciennes provinces des Pays-Bas, Bruxelles 1873 . Deze penning is van zilver, terwijl in het signaat van 1663 sprake is van een gouden. Iet Rekenboek van 1667 heldert deze moeilijkheid, naar ik geloof, op. Hierin komen voor deze posten:

"Uit de breucken aen den Heere Borgermr. Melchiok TeN Hove betaelt 150 gld, soo sijn Ed. voor eenen "gouden ende silveren penningh, gelijck andere Borgermr. getrocken hebben, toegelegt."

"Aan Borgerm. BEECKMAN 50 gld. sijn Ed. per reste boven den gouden penninck inmpeterende." Om dezelfde reden krijgen GOK1s en SINGENDONCK ook nog 50 gld. tot supplement op hunne gouden penningen. Mij dunkt, er was zoovecl geld, dat aan den gouden penning nog een zilveren voor jeder toegevoegd kon worden, welke een waarde van 50 gld. vertegenwoordigde. In 1669,1670 en 1671 wordt de som van 150 gid. in de Rekenboeken vermeldt, als betaald aan Willem Water, Hetkelom en van dix Bergh. 
o hr steeds klaar arme studenten te steunen, wanneer de studiën voor een particuliere beurs te zwaar vielen. De zoon van professor MANDEVILLE krijgt jaarlijks 75 gulden ter voltooiing van zijn studie, evenzoo AвRAHAM GuLichiUs. 50 gulden worden bestemd voor HENDIR DE BEIJER, en in het Rekenboek van I 665 komt de post voor: "betaelt aan Kocmius GREvenBROECK, student in de theologie, 6 gld. voor een viaticum." Evenzoo was de Raad zeer mild, wanneer de theses moesten gedrult worden voor een disputatie, vooral in gevallen als in Januari 1660 , toen een student uit het pausdom overging, of in 166I, toen een student „Luters gesint geweest sijnde ende nu onder WitTichius studeerende” onder den voorn. professor wilde disputeeren. Zoo ook keek men op verzoek der studenten naar een muziekmeester om, opdat zij zouden leeren zingen en spelen op cornet, viool en andere instrumenten. Deze mildheid miste de uitwerking niet, vele studenten kwamen naar Nijmegen. Reeds op 3 Mei 1656 kon Witrichius, toen hij het rectoraat aan zijn ambtgenoot DE GREVE overdroeg, in zijn oratie: „Gibea Gelria, sive oratio, qua convenientia inter Gibeam Benjaminis et Neomagum demonstratur," met trots wijzen op het welslagen der academie. "Gibea, separans Judaeos Dei confessores ab Israëlitis idololatris," had groote overeenkomst met Nijmegen. Nijmegen en Gibea waren middelpunten, waarheen alles samenstroomde.

Zie hier in hoofdtrekken de geschiedenis van de Nijmeegsche academie, de "Illustris Tetrarchiae Noviomagensis Universitas", zooals op het poortje staat, dat nu is overgebracht naar de binnenplaats van het stadhuis. In al te veel bijzonderheden ben ik niet afgedaald. NIJHOFF en VAN DER MEER vaN KUFFELER hebben dit voor mij reeds gedaan. Door mij zijn alleen besproken eenige moeilijke punten, welke men tot nu toe of niet of slechts ter loops te berde had gebracht, en verder heb ik gretracht door uit nicuwe bronnen nog het een en ander te halen de geschiedenis dezer instelling aan te vullen. Niet genoeg dankbaar kan ik zijn voor de hulp en bereidvaardigheid, die ik tijdens mijne verblijven te Nijmegen van den ijverigen archivaris H. D. J. van Schevichaven ondervond. Zijn groote kennis van Nijmeegsche toestanden kwam mij dikwijls te stade. Als slot nog een enkel woord over de pogingen, door enkele mannen gedaan tot herstelling van de academie.

De pogingen van CORnelis Walraven VoNCK in 1756 zijn door mij vroeger uitvoerig besproken ${ }^{1}$ ), zoodat alleen overblijft te vermelden wat JoHANNES IN DE BETOUW I4 November I 798 in het werk stelde voor een mogelijke restitutie. Als raadslid bood hij de vergadering een concept-missive aan, bestemd voor de Eerste Kamer van het vertecrenwoordigend lichaam des Bataafschen volks. De inhoud komt hierop neer. I 8 Augustus had de Raad de stad Nijmegen aanbe-

1) Zie Oud Holland, 1899 . 
volen als zetel voor cen departementaal gerechtshof, „uit hoofde van de geschiktheid van de daartoe alhier gevonden wordende locaalen en ter zaake van 't groot verlies, 't welk deese stad is lijdende door 't gemis van de landelijke en quartierlijke collegien, die binnen dezelve pleegden te vergaderen." De aanhoudende stremming in den tevoren bloeienden handel door nieuw ingevoerde belastingen had groote schade gebracht en daarvoor mocht zeker wel een kleine vergoeding als tegenwicht komen. Als tegenwicht had kunnen dienen het gerechtshof, maar er werd anders besloten. 's-Hertogenbosch wees men aan als zetel zoowel voor het rechterlijk als administratief lichaam van het zevende departement van den Dommel. Thans kwam Nijmegen met een ander verzoek. „Het is UE. — dit zijn de woorden van de missive - bekend, dat de stad Nijmegen in de voorige ceuw eene quartierlijke Academie en Universiteit binnen haare muuren heeft gehad, met alle vrijheden en voorregten van hooge schoolen voorzien, waarin re Senatus Academicus regt oeffende over Burgerlijke en straf baare zaaken, Dat de beroemdste mannen van ongemeene letterkunde, aan welkers geleerdheid men zeer veel is verpligt, van andere en wel voornaame Academien herwaards beroepen, alhier gelecraard hebben: Dat, om een aantal van voortreffelijke te Nijmegen gepromoveerde mannen voorbij te gaan, Gerhardus Nood'T en Axtonius Schuiting '), voormaals schittcrende ligten in de Regtsgeleerdheid aan de hoogeschool van Leiden en binnen Nijmegen geboorein, hunne studien op de Nijmeegsche Academie niet alleen hebben volbragt, maar de eerstgem. ook aan dezelve Hoogleeraar is geweest, En dat de bloei deeser Academie heeft voortgeduurd tot 't noodlottig jaar I672, na 't welk de subsidien, die de Academie van 't voormalig qnarticr van Nijmegen genoot, ingetrokken en aan de vervalle Academie tc Harderwijk, welke op de gewigtige voorspraak en 't aanhouden van den doenmaaligen stadhouder WILLEM III was hersteld, verleend wierden. Geschikte locaalen zijn alsnog voorhanden en de aangenaame legging der stad aan de groote Rivier de Waal, mitsgaders de gemakkelijke toegang tot dezelve van rondsomme, zijn geen geringe redenen. die meede voor onsen voordragt pleiten.

Waarmede Burgers Vertegenwoordigers! wij UL. beveclen in Gods heilige bescherminge. Geschreven te Nijmegen den I $4^{\text {en }}$ November 1798 , 't vierde jaar der Bat. Vrijheid."

De Raad keurde het concept goed, maar de moeite was te vergeefsch.

1) Hij was de zoon ran den Nijmeegschen professor JohAxגes Schiltivg, die begin September ru66 aan de pest stierf. Eerst 9 Januari 1667 hield WrTticilus de lijkrede, daar professoren en studenten gevlucht waren. Zijne papieren krees Graevius. Deze rond hierin reel, wat hij kon gebruiken voor zijn editic van Quintmianus. Naar aanleiding van dit droevig sterfgeval vroeg Graevil's aan Heinsius, of hij met een liort gedicht den overledene wilde verheerijken. Hissit's antwoordde, dat hij er niet toe gerreigd was. „Me jam piget inter istas nugas consencsccre, ex quibus tantum abest emolumenti aut lucelli quicquam teduidare, ut vix plausum consequaris." Schultikg kon trouwens terreden rijn, zeven mannen voelden zich gerocpen zijn lof to bezingen. 